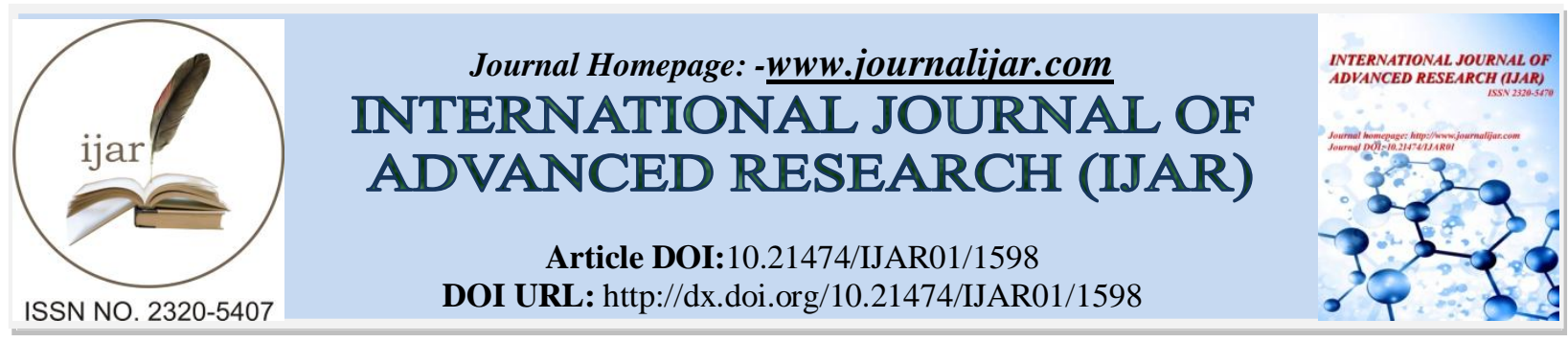

RESEARCH ARTICLE

\title{
WATER CONSUMPTION VARIABILITY FOR MAJOR CROPS IN EGYPT UNDER CLIMATE CHANGE CONDITIONS.
}

\author{
Khalil A.A., Y.H. Essa, F.A. Hashem and K.M. Refaie \\ Central Laboratory for Agricultural Climate (CLAC), Agricultural Research Center (ARC), Ministry of Agriculture \\ and Land Reclamation (MALR), Egypt.
}

\section{Manuscript Info}

[.......................

Manuscript History

Received: 16 July 2016

Final Accepted: 22 August 2016

Published: September 2016

Key words:-

Water Consumption, Climate Change, Major Crops (Rice, Potato, Tomato and Wheat)

\section{Abstract}

Egypt appears to be particularly vulnerable to climate change especially with water scarcity problem. Climate change not only affects the spatial and temporal distribution of water resources, but also will increase the crop evapotranspiration. The aim of this paper is to assess the impact of climate change on water consumptive use for six main major crops in Egypt (rice, summer potato, summer tomato, wheat, winter potato, and winter tomato). The climate change data has been developed from downscaling of global climate model ECHAM6 of scenario RCP. 4.5 by a horizontal resolution $50 \mathrm{~km}$ during the period from 2010 up to 2090, and the water consumption has been assessing at the governorates that have largest areas of determined crops distributed in different geographic regions. The obtained results indicate that, climate change conditions expected to increase water consumption for all examined regions in Egypt, and the most effect will be in Upper Egypt and specific areas in Lower Egypt region. The results also indicated to extreme increment [decrement] will effect during 2070 and 2080 [2050 and 2060] decades in Dakahlia [Aswan and Minya] governorates. Also the study concluded that, the impact of climate change on water consumption is limited and acceptable up to 2040 for the studied crops among the determined governorates and it not excessed 5\% than its current, however, after this period the rate of increment transit to higher level, and sharp extreme effects appeared in some regions.

Copy Right, IJAR, 2016,. All rights reserved.

\section{Introduction:-}

Climate change is expected to exacerbate this situation by increasing potential evapotranspiration, decreasing rainfall and increasing the frequency and intensity of droughts (Nianget al., 2014; IPCC, 2014). Temperature raise as projected by many climatological studies will lead to highly increased evapotranspiration on the territory of Egypt especially because of the traditionally irrigated agriculture. Besides, the projected high temperature would increase the local water demands especially on the agricultural sector. Limited water resources and scarcity of water in Egypt is the main challenge for agricultural horizontal expanding under current and future climate. All crops are projected to have a decrease in yields and an increase in irrigation needs. Some crops only decrease a few percent while others have a reduction of more than one-fourth (UNDP 2013). Egypt as an arid country relying on the Nile River which

Corresponding Author:-Khalil A.A.

Address:-Central Laboratory for Agricultural Climate (CLAC), Agricultural Research Center (ARC), 
provides $95 \%$ of its water resources is suffering water stress due to the limited supplies and growing population, and increased competition on water from the upper Nile basin countries. Water management in Egypt is further pressured by uncertain climate change impacts on the Nile flow (Nour El-Din 2013). According to UNESCO around $70 \%$ of total used freshwater is consumed by agriculture. This number is even higher for Egypt and increases up to $77 \%$ in order to afford food security (El-Shirbenyet al., 2014). . As such, Egypt faces many challenges of current and future water scarcity. Egypt has reached a state where the quantity of water available is imposing limits on its national economic development. As indication of scarcity in absolute terms, often the threshold value of 1000 $\mathrm{m}^{3} /$ capita/year is used. Egypt has passed that threshold already in nineties. As a threshold of absolute scarcity 500 $\mathrm{m}^{3} /$ capita/year is used, this will be evident with population predictions for 2025 which will bring Egypt down to $500 \mathrm{~m}^{3} /$ capita/year (MWRI, 2014). Globally, around 70 percent of all freshwater withdrawals are used for food production. Over the past four decades, irrigation has undoubtedly contributed to an increase in global crop yields, allowing global food production to keep pace with population growth (United Nations 2006).Previous research was done in Egypt on the effect of climate change on water requirements for crops. It revealed that it will increase by $16 \%$ for summer crops compared to their current requirements under current conditions. Furthermore, climate change conditions could decrease water demand for winter crops up to $2 \%$ in the year of 2050 (Eid and ElMowelhi, 1998). According to (Oudaet al., 2011) under temperature increase by $2^{\circ} \mathrm{C}$, the total required water for agriculture in the Arabic countries will be increased by a percentage between $9 \%$ and $36 \%$. The large variation in the previous percentage is mainly due to population growth and increasing demand for water assigned for agriculture. Also according to Oudaet al. (2011) developed a prediction equation to calculate total water requirements needed to support irrigation in Egypt in 2025 and concluded that an increase by 33\% is expected to occur. Oudaet al. (2015) indicated that annual PET values will increase by $8 \%$ and water requirements for wheat and maize will increase by 2 and15\%, respectively in 2040 at El-Behira governorate (North Egypt).The objective of the present study is to evaluate the water requirements of key crops in Egypt under climate change in Egypt

\section{Material and Methods:-}

\section{Study area:-}

The study was carried out on the governorate which have largest cultivated area distributed in different geographic regions (Lower, Middle, and Upper Egypt) of determined crops. Governorates have been selected based on the Bulletin of the Agricultural Statistics (BAS) 2013 and 2014.

\section{Climate data:-}

The climate change data has been developed from downscaling the global climate model (ECHAM6) of scenario RCP (Representative Concentration Pathways). 4.5 by a horizontal resolution $50 \mathrm{~km}$ using regional climate model (RegCM 4). The climate parameters of (temperature, relative humidity, solar radiation, wind speed, and precipitation) have been exported and processed from 2010 up to 2090 to calculate evapotranspiration and water consumption.

\section{Water consumption:-}

Assessing the water consumption $\mathrm{ET}_{\mathrm{c}}$ for six strategic crops representing both summer and winter season (Rice, summer potato, summer tomato, wheat, winter potato, and winter tomato) under climate change in Egypt had been done according to equation (1). The averages of results for each 10 seasons were calculated to study the effect of climate change on the water consumption for selected crops.

$E T_{c}=k_{c} \times E T_{o}$

Where ETo is the reference evapotranspiration and has been estimated using FAO Penman-Monteith method (Allen et al. 1998), and $\mathrm{K}_{\mathrm{c}}$ is the crop coefficient and has been determined according to growth stages of each crop.

\section{Estimation of evapotranspiration:-}

The FAO Penman-Monteith method is recently recommended as the sole standard method when all data required are available (Allen et al, 1998). It is a method with strong likelihood of correctly predicting $\mathrm{ET}_{\mathrm{o}}$ in a wide range of locations and climates. The FAO Penman-Monteith method to estimate ETo is expressed as:

$$
E T_{o}=\frac{0.408 \Delta\left(R_{n}-G\right)+\gamma \frac{900}{T+273} u_{2}\left(e_{s}-e_{a}\right)}{\Delta+\gamma\left(1+0.34 u_{2}\right)}
$$


Where $\mathrm{ETo}=$ reference evapotranspiration $(\mathrm{mm}$ day- 1$) ; \mathrm{Rn}=$ net radiation at the crop surface $(\mathrm{MJ} \mathrm{m}-2 \mathrm{Day}-1) ; \mathrm{G}=$ soil heat flux density (MJ m-2 day-1); $\mathrm{T}=$ mean daily air temperature at $2 \mathrm{~m}$ height (0C); $\mathrm{U} 2=$ wind speed at $2 \mathrm{~m}$ height ( $\mathrm{m} \mathrm{s}-1)$; es = saturation vapour pressure $(\mathrm{KPa})$; ea = actual vapour pressure $(\mathrm{KPa})$; es - ea = saturation vapour pressure deficit $(\mathrm{KPa}) ; \Delta=$ slope vapour pressure curve $(\mathrm{KPa} 0 \mathrm{C}-1) ; \gamma=$ psychrometric constant $(\mathrm{KPa} 0 \mathrm{C}$ $1)$;

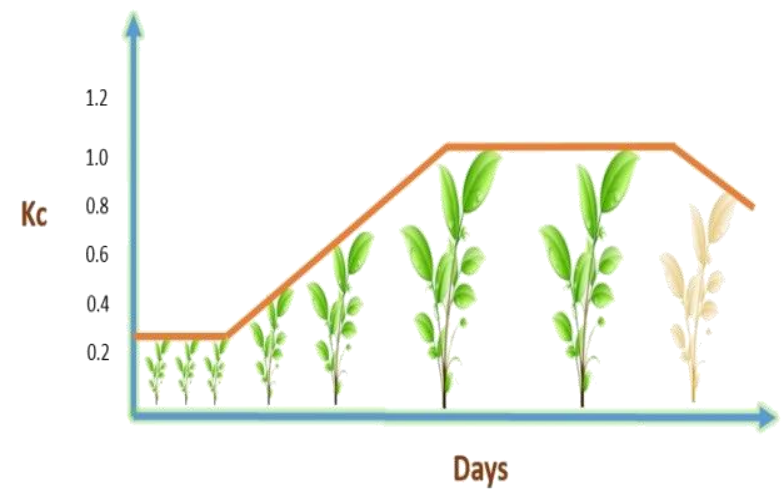

Figure (1): Crop coefficient $K_{c}$ variation curve according to crop growth stages.

\section{Crop coefficient $(\mathrm{Kc})$ for different main crops:-}

The project of Kc was introduced by Jensen (1968) and further developed by the other researchers (Doorenbos and Pruitt, 1975, 1977; Burmanet al., 1980a, Burmanet al., 1980b; Allen et al., 1998). The crop coefficient is the ratio of the potential crop evapotranspiration $(\mathrm{ETc})$ to reference crop evapotranspiration $\left(\mathrm{ET}_{\mathrm{o}}\right)$ and it integrates the effects of characteristics that distinguish field crops from grass, like ground cover, canopy properties and aerodynamic resistance.

The FAO and WMO (World Meteorological Organization) experts have summarized such evolution in the "crop coefficient curve" to identify the Kc value corresponding to the different crop development and growth stages (initial, middle and late, hence it has Kc in, Kc mid, Kc end) (Tarantino and Spano, 2001). Values of Kc for most agricultural crops increase from a minimum value at planting until maximum $\mathrm{Kc}$ is reached at about full canopy cover.

The Kc tends to decline at a point after a full cover is reached in the crop season. The declination extent primarily depends on the particular crop growth characteristics (Jensen et al., 1990) and the irrigation management during the late season (Allen et al., 1998).

\section{Results and Discussion:-}

\section{Evapotranspiration values:-}

The results of this study divided into averages each ten years during the seasons from (2011-2090) at the studied governorates for the selected crops.

Evapotranspiration values $\left(\mathrm{m}^{3} / \mathrm{feddan}{ }^{1}\right)$ at the studied governorates for the selected crops are shown in table (1) and it has been indicated that, the evapotranspiration directed to increase in the future in all studied governorates taking in the consideration the geographic locations level (lowest values in Lower Egypt and highest values in Upper Egypt).

Also it has been observed an extreme increment in Eto values at Dakahlia during 2070 and 2080 decades even it exceeded upper Egypt values, and at Gharbia during 2060 decade, and an extreme decrement at Minya during 2060 decade and at Aswan during 2050 decade.

\footnotetext{
${ }^{1} 1$ feddan $=42000 \mathrm{~m}^{2}$
} 
Table 1:- Average evapotranspiration values (m³/feddan) each 10 years for the years from 2011 up to 2090.

\begin{tabular}{|c|c|c|c|c|c|c|c|c|}
\hline & $\begin{array}{l}2011- \\
2020\end{array}$ & $\begin{array}{l}2021- \\
2030\end{array}$ & $\begin{array}{l}2031- \\
2040\end{array}$ & $\begin{array}{l}2041- \\
2050\end{array}$ & $\begin{array}{l}2051- \\
2060\end{array}$ & $\begin{array}{l}2061- \\
2070\end{array}$ & $\begin{array}{l}2071- \\
2080\end{array}$ & $\begin{array}{l}2081- \\
2090\end{array}$ \\
\hline Alexandria & 6.3 & 6.5 & 6.4 & 6.5 & 6.6 & 6.7 & 6.6 & 6.8 \\
\hline Behera & 6.3 & 6.4 & 6.4 & 6.4 & 6.5 & 6.6 & 6.6 & 6.7 \\
\hline Kafr El-sheikh & 6.3 & 6.4 & 6.4 & 6.5 & 6.5 & 6.6 & 6.6 & 6.7 \\
\hline Ismailia & 6.5 & 6.6 & 6.7 & 6.7 & 6.8 & 6.9 & 6.9 & 7.0 \\
\hline Dakahlia & 6.5 & 6.6 & 6.7 & 6.7 & 6.8 & 7.2 & 10.0 & 9.6 \\
\hline Monufia & 6.7 & 6.8 & 6.8 & 6.9 & 7.0 & 7.1 & 7.1 & 7.2 \\
\hline Gharbia & 6.8 & 6.9 & 6.9 & 7.0 & 7.1 & 7.7 & 7.2 & 7.3 \\
\hline Sharqia & 6.9 & 7.0 & 7.0 & 7.1 & 7.1 & 7.3 & 7.3 & 7.4 \\
\hline Faiyum & 7.1 & 7.2 & 7.2 & 7.3 & 7.4 & 7.5 & 7.5 & 7.6 \\
\hline Beni Suef & 7.2 & 7.3 & 7.3 & 7.4 & 7.5 & 7.6 & 7.6 & 7.7 \\
\hline Giza & 7.3 & 7.4 & 7.4 & 7.5 & 7.6 & 7.7 & 7.7 & 7.8 \\
\hline Minya & 7.6 & 7.6 & 7.7 & 7.7 & 7.7 & 6.8 & 8.0 & 8.1 \\
\hline Asyut & 7.7 & 7.7 & 7.9 & 7.9 & 8.0 & 8.1 & 8.2 & 8.2 \\
\hline Sohag & 8.6 & 8.6 & 8.7 & 8.7 & 8.9 & 9.0 & 9.0 & 9.1 \\
\hline Qena & 8.5 & 8.5 & 8.7 & 8.6 & 8.8 & 9.0 & 9.0 & 9.0 \\
\hline Aswan & 9.4 & 9.5 & 9.6 & 9.4 & 8.1 & 9.9 & 9.9 & 9.9 \\
\hline
\end{tabular}

]-

Red cells are the extreme increment, and blue cells are the extreme decrement.

Water consumption for selected summer crops:-

Rice:-

Rice crop has been studied in five governorates which are Dakahlia, Kafr El-sheikh, Sharqia, Behera, and Gharbia according to Ministry of Supply and Ministry of Water Resources and irrigation in collaborate with Ministry of Agriculture determination in 2016 (Parlmany' ${ }^{2016) 2}$. Table (2) shows the water consumption of rice during the seasons from (2011-2090) divided into averages each ten years of study period and it has been observed that, Sharqia governorate is the highest water consumption in current and future condition up to 2070 season and after this time Dakahlia governorate jumped to highest results among the studied governorates during the study period, while Kafr El-sheikh kept its position the lowest rice water consumption in current and under future condition. Also it has been found that, water consumption is increasing with time and the period of (2011-2020) has the lowest values in all governorates among the studied periods while the highest one was (2061-2070) in all governorates except in Dakahlia which shows its highest water consumption during the (2071-2080) period. The changing rate has been calculated in relative to (2011-2020) period and the result has been shown in figure (2) which indicated that, all periods of studied governorate will increase than (2011-2020) period, however, (2061-2070) is a milestone period than its pervious where the increment rate has been ranged from 2 up to $7 \%$ greater than the base period during the seasons from 2021 up to 2060 while has been ranged from 7 up to $23 \%$ after this period and continued in this range up to 2090. Also it has been observed an extreme increment in Dakahlia governorate after 2070 season and its rate was above 50\% than base period from 2071 up to 2090.

\footnotetext{
${ }^{2}$ http://www.parlmany.com/News/10/80754/\%D8\%AA\%D8\%B9\%D8\%B1\%D9\%81-\%D8\%B9\%D9\%84\%D9\%89\%D8\%A7\%D9\%84\%D9\%85\%D8\%AD\%D8\%A7\%D9\%81\%D8\%B8\%D8\%A7\%D8\%AA\%D8\%A7\%D9\%84\%D9\%85\%D8\%B3\%D9\%85\%D9\%88\%D8\%AD-\%D9\%84\%D9\%87\%D8\%A7\%D8\%A8\%D8\%B2\%D8\%B1\%D8\%A7\%D8\%B9\%D8\%A9-\%D8\%A7\%D9\%84\%D8\%A3\%D8\%B1\%D8\%B2\%D9\%88\%D9\%85\%D8\%A7-\%D9\%87\%D9\%89-\%D8\%A7\%D9\%84\%D8\%B9\%D9\%82\%D9\%88\%D8\%A8\%D8\%A9
} 
Table 2:-Average water consumption amount ( $\mathrm{m}^{3} /$ feddan) for rice crop in the periods form (2011-2020) up to $(2081-2090)^{3}$.

\begin{tabular}{|c|c|c|c|c|c|}
\hline \multicolumn{5}{|c|}{ Rice Crop } \\
\hline Date & Dakahlia & Kafr El-sheikh & Sharqia & Behera & Gharbia \\
\hline $\mathbf{2 0 1 1}-\mathbf{2 0 2 0}$ & 3638 & 3410 & 3828 & 3476 & 3767 \\
\hline $\mathbf{2 0 2 1}-\mathbf{2 0 3 0}$ & 3713 & 3488 & 3898 & 3550 & 3840 \\
\hline $\mathbf{2 0 3 1}-\mathbf{2 0 4 0}$ & 3730 & 3505 & 3924 & 3557 & 3868 \\
\hline $\mathbf{2 0 4 1}-\mathbf{2 0 5 0}$ & 3744 & 3518 & 3927 & 3575 & 3868 \\
\hline $\mathbf{2 0 5 1}-\mathbf{2 0 6 0}$ & 3837 & 3605 & 4028 & 3668 & 4020 \\
\hline $\mathbf{2 0 6 1}-\mathbf{2 0 7 0}$ & 4112 & 3680 & 4100 & 3739 & 4628 \\
\hline $\mathbf{2 0 7 1}-\mathbf{2 0 8 0}$ & 5737 & 3652 & 4077 & 3711 & 4020 \\
\hline $\mathbf{2 0 8 1}-\mathbf{2 0 9 0}$ & 5470 & 3669 & 4080 & 3722 & 4016 \\
\hline
\end{tabular}

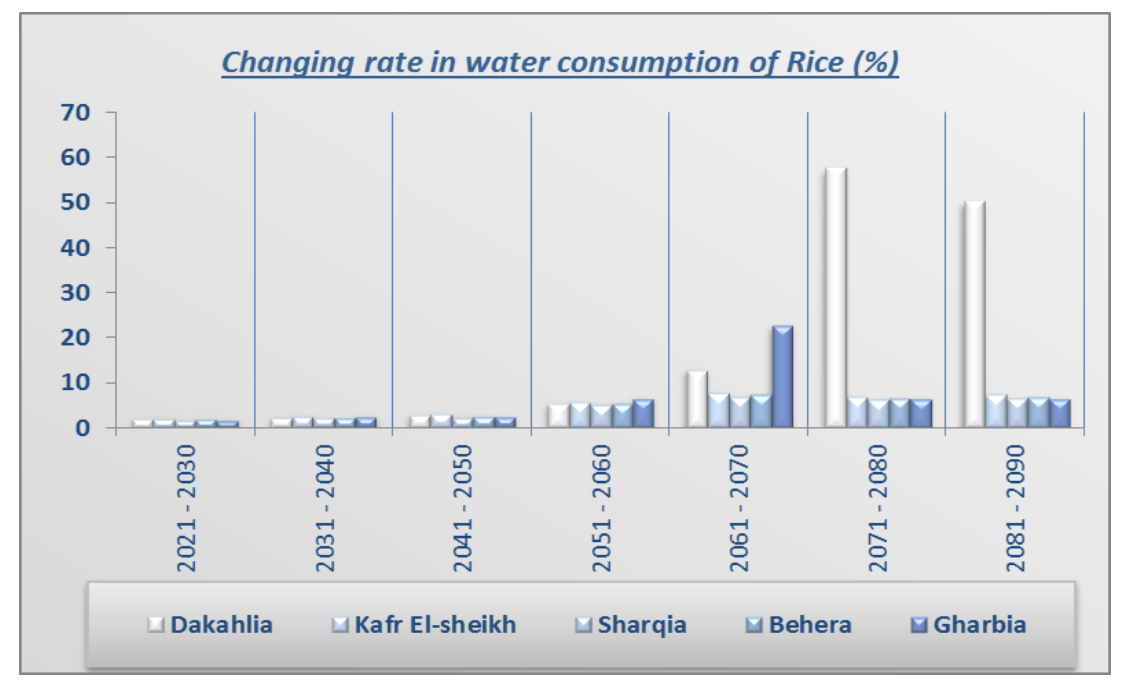

Figure 2:-Changing rate percentage than (2011-2020) in water consumption of rice at selected governorates.

\section{Summer Potato:-}

Potato of summer season has been studied in the governorates of Behera\&Monufia in Lower Egypt, Giza \&Minya in Middle Egypt, and Asyut \&Aswan in Upper Egypt which are the highest agricultural area in each region according to (BAS, 2013) Table (3) shows the water consumption of summer potato during the seasons from (2011-2090) divided into averages each ten years of study period and it has been observed that, water consumption is increasing with time and the (2011-2020) period has the lowest values in all governorates except in Minya and Aswan where their lowest values has been observed in (2061-2070) and (2051-2060) periods respectively, while the highest water consumption was found in the period of (2081-2090) at all studied governorates. The changing rate has been also calculated in relative to (2011-2020) period and the result has been shown in figure (3) which indicated that, all periods of studied governorate will increase than (2011-2020) period except Aswan which will decrease its water consumption about 20\% in 2050 decade and Minya which will decrease also by $6 \%$ than base period. The highest increment rate than base period found in 2080 decade and it was ranged between 8 to $10 \%$, while the lowest rate found in 2020 decade by values ranged from 2 to $3 \%$. The lowest governorate affected by climate change condition in water consumption of summer potato was Behera while the highest one was Asyut governorate.

${ }^{3}$ Colored cells indicate to Highest (orange cell) and lowest (blue cells) water consumption each 10 seasons for the selected crops 
Table 3:-Average water consumption amount (m3/feddan) for summer potato in the periods form (2011-2020) up to (2081-2090).

\begin{tabular}{|c|c|c|c|c|c|c|}
\hline \multicolumn{7}{|c|}{ Summer Potato } \\
\hline Date & Behera & Monufia & Giza & Minya & Asyut & Aswan \\
\hline $\mathbf{2 0 1 1}-\mathbf{2 0 2 0}$ & 1954 & 2088 & 2250 & 2303 & 2337 & 3084 \\
\hline $\mathbf{2 0 2 1}-\mathbf{2 0 3 0}$ & 2009 & 2145 & 2305 & 2352 & 2379 & 3174 \\
\hline $\mathbf{2 0 3 1}-\mathbf{2 0 4 0}$ & 1979 & 2128 & 2302 & 2358 & 2395 & 3197 \\
\hline $\mathbf{2 0 4 1}-\mathbf{2 0 5 0}$ & 2020 & 2166 & 2341 & 2403 & 2425 & 3146 \\
\hline $\mathbf{2 0 5 1}-\mathbf{2 0 6 0}$ & 1971 & 2121 & 2307 & 2354 & 2418 & 2486 \\
\hline $\mathbf{2 0 6 1}-\mathbf{2 0 7 0}$ & 2028 & 2189 & 2374 & 2175 & 2477 & 3252 \\
\hline $\mathbf{2 0 7 1}-\mathbf{2 0 8 0}$ & 2023 & 2180 & 2373 & 2455 & 2504 & 3307 \\
\hline $\mathbf{2 0 8 1}-\mathbf{2 0 9 0}$ & 2103 & 2266 & 2463 & 2540 & 2573 & 3333 \\
\hline
\end{tabular}

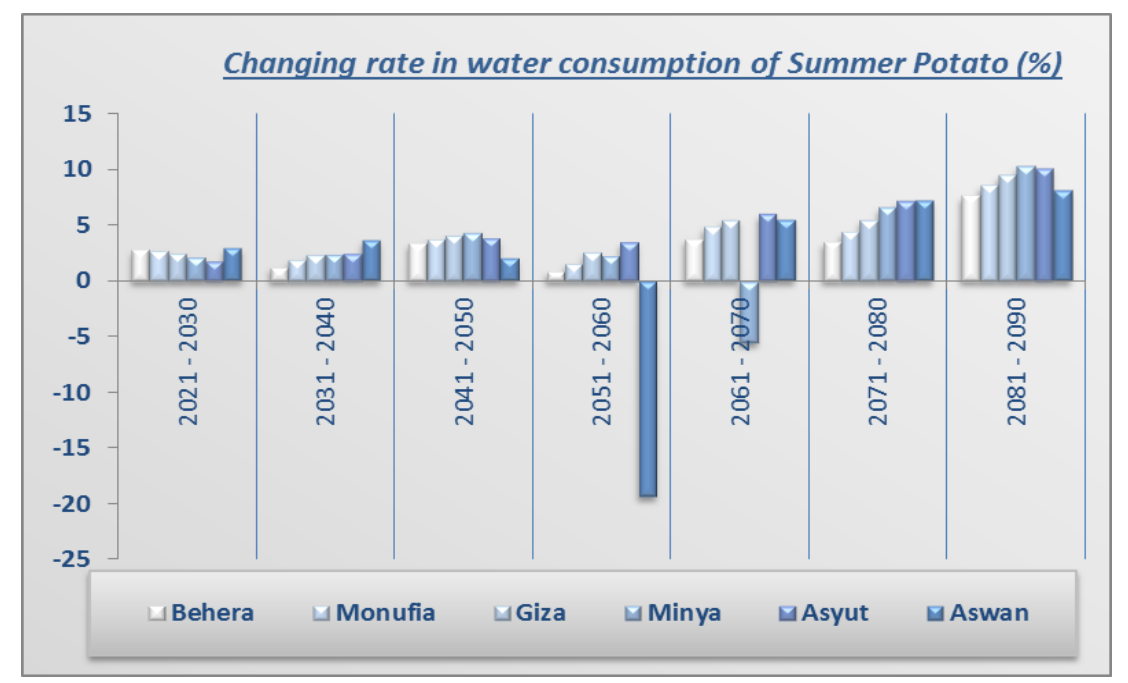

Figure 3:-Changing rate percentage than (2011-2020) in water consumption of summer potato at selected governorates.

\section{Summer Tomato:-}

Tomato of summer season has been studied in the governorates of Alexandria \&Behera in Lower Egypt, Giza \&Minya in Middle Egypt, and Asyut \&Sohag in Upper Egypt which are the highest agricultural area in each region according to (BAS, 2013)

Table (4) shows the water consumption of summer tomato during the seasons from (2011-2090) divided into averages each ten years of study period and it has been observed that, the highest water consumption was found in (2061-2070) period at all studied governoratesexcept in Minya where its highest value was found in (2081-2090) period, while the lowest vales has not been observed in specific period where it was in (2031-2040) period at Alexandria and Giza governorates, in (2011-2020) at Behera governorate, in (2061-2070) at Minya governorate, in (2021-2030) at Asyut and Sohag governorates. 
Table 4:-Average water consumption amount (m3/feddan) for summer tomato crop in the periods form (2011-2020) up to (2081-2090).

\begin{tabular}{|c|c|c|c|c|c|c|}
\hline \multicolumn{7}{|c|}{ Summer Tomato } \\
\hline Date & Alexandria & Behera & Giza & Minya & Asyut & Sohag \\
\hline $\mathbf{2 0 1 1}-\mathbf{2 0 2 0}$ & 2596 & 2571 & 3037 & 3181 & 3224 & 3514 \\
\hline $\mathbf{2 0 2 1}-\mathbf{2 0 3 0}$ & 2642 & 2617 & 3044 & 3145 & 3184 & 3491 \\
\hline $\mathbf{2 0 3 1}-\mathbf{2 0 4 0}$ & 2579 & 2573 & 3012 & 3125 & 3184 & 3491 \\
\hline $\mathbf{2 0 4 1}-\mathbf{2 0 5 0}$ & 2651 & 2640 & 3079 & 3198 & 3252 & 3569 \\
\hline $\mathbf{2 0 5 1}-\mathbf{2 0 6 0}$ & 2631 & 2623 & 3074 & 3110 & 3233 & 3542 \\
\hline $\mathbf{2 0 6 1}-\mathbf{2 0 7 0}$ & 2721 & 2711 & 3171 & 2640 & 3355 & 3671 \\
\hline $\mathbf{2 0 7 1}-\mathbf{2 0 8 0}$ & 2690 & 2687 & 3157 & 3291 & 3344 & 3657 \\
\hline $\mathbf{2 0 8 1}-\mathbf{2 0 9 0}$ & 2705 & 2697 & 3164 & 3317 & 3348 & 3650 \\
\hline
\end{tabular}

The changing rate has been also calculated in relative to (2011-2020) period and the result has been shown in figure (4) which indicated that, the water consumption of decades 2040, 2070, and 2080 will increase than base period at all studied governorates and the rate of increment was the highest in 2080 decade where it ranged between 4-5\%, while it was the lowest in 2040 decade and ranged between 1-3\%.

Also it has been observed that water consumption of summer tomato will decrease than base period at all studied governorates by values ranged between 1-2\% in 2030 decade, in addition the results indicated to extreme decrement projected in Minya governorate in 2060 decade and it was about more than 15\% lower than base period.

The highest governorate affected by climate change condition in water consumption of summer tomato was Behera while the lowest one was Minya governorate, and it's worth to mentioning that water consumption of summer tomato in Upper Egypt governorates will decrease in 2020 and 2030 period and starting its effect by increase after 2030 .

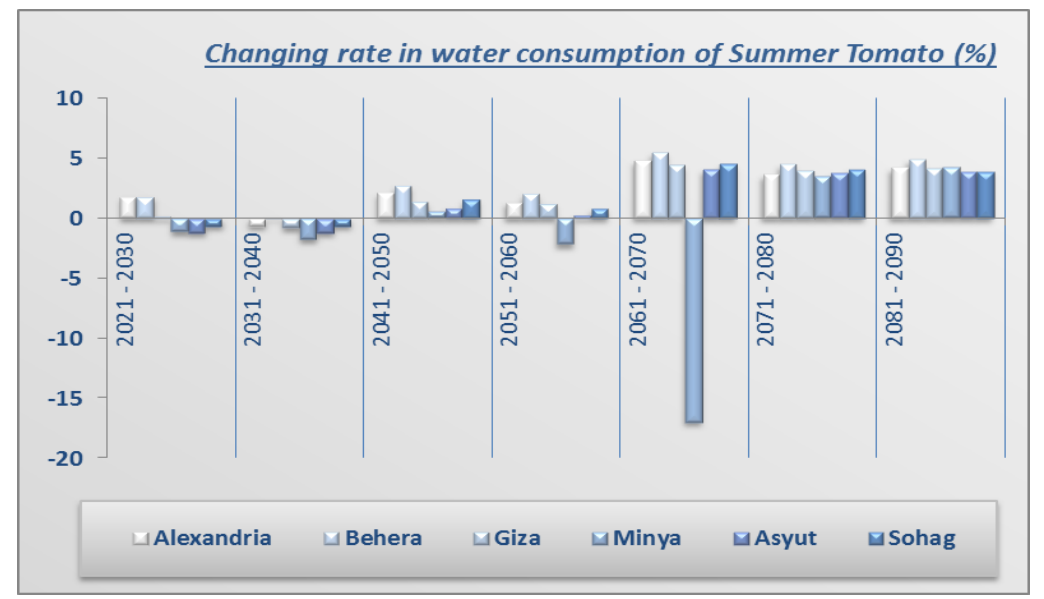

Figure 4:-Changing rate percentage than (2011-2020) in water consumption of summer tomato at selected governorates.

\section{Water consumption for selected winter crops:-}

\section{Wheat:-}

Wheat crop has been studied in the governorates of Sharqia\&Behera in Lower Egypt, Faiyum\&Minya in Middle Egypt, and Asyut \&Sohag in Upper Egypt which are the highest agricultural area in each region according to (BAS, 2013) Table (5) shows the water consumption of wheat during the seasons from (2011-2090) divided into averages each ten years of study period and it has been observed that, water consumption of wheat crop is increasing with 
time and (2011-2020) period has the lowest values in all studied governorates except Minya which observed its lowest vale in (2061-2070) period, while the highest wheat water consumption has been observed in (2081-2090) period in all studied governorates. Also it has been found that Behera and Sohag governorate were the lowest and highest wheat water consumption in current and future condition respectively.

Table 5:-Average water consumption amount ( $\mathrm{m}^{3} /$ feddan) for wheat crop in the periods form (2011-2020) up to (2081-2090).

\begin{tabular}{|c|c|c|c|c|c|c|}
\hline \multicolumn{7}{|c|}{ Wheat } \\
\hline Date & Sharqia & Behera & Faiyum & Minya & Asyut & Sohag \\
\hline $\mathbf{2 0 1 1}-\mathbf{2 0 2 0}$ & 1877 & 1703 & 1885 & 2017 & 2042 & 2291 \\
\hline $\mathbf{2 0 2 1}-\mathbf{2 0 3 0}$ & 1919 & 1750 & 1921 & 2048 & 2074 & 2337 \\
\hline $\mathbf{2 0 3 1}-\mathbf{2 0 4 0}$ & 1910 & 1718 & 1923 & 2047 & 2085 & 2353 \\
\hline $\mathbf{2 0 4 1}-\mathbf{2 0 5 0}$ & 1924 & 1744 & 1929 & 2057 & 2091 & 2359 \\
\hline $\mathbf{2 0 5 1}-\mathbf{2 0 6 0}$ & 1897 & 1705 & 1922 & 2013 & 2074 & 2343 \\
\hline $\mathbf{2 0 6 1}-\mathbf{2 0 7 0}$ & 1958 & 1757 & 1991 & 1822 & 2163 & 2427 \\
\hline $\mathbf{2 0 7 1}-\mathbf{2 0 8 0}$ & 1978 & 1777 & 2007 & 2137 & 2180 & 2464 \\
\hline $\mathbf{2 0 8 1}-\mathbf{2 0 9 0}$ & 2023 & 1820 & 2064 & 2212 & 2238 & 2507 \\
\hline
\end{tabular}

The rate of change in wheat water consumption in relative to (2011-2020) period has been calculated and the result has been shown in figure (5) which indicated that, the water consumption of wheat crop will increase than base period in all studied governorates during study period except in Minya of 2060 decade which decrease its water consumption about 10\% than base period. The rate of increment was lowest in 2050 decade where it has been ranged between $0-2 \%$, while it was the highest in 2080 decade and has been ranged between $7-10 \%$ among the studied governorates.

The lowest governorate affected by climate change condition in water consumption of wheat crop was Behera while the highest effect has been observed in Sohag governorates.

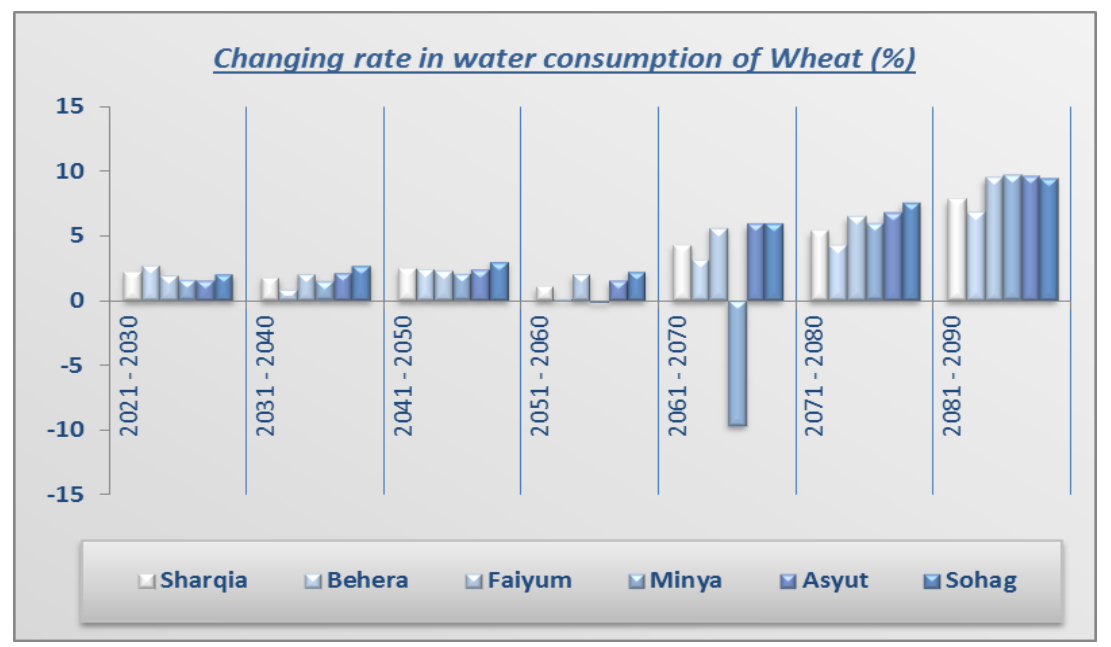

Figure 5:-Changing rate percentage than (2011-2020) in water consumption of wheat crop at selected governorates.

\section{Winter Potato:-}

Potato crop of winter season has been studied in the governorates of Dakahlia\&Behera in Lower Egypt, BeniSuef\& Giza in Middle Egypt, and Sohag\& Aswan in Upper Egypt which are the highest agricultural area in each region according to (BAS, 2013) Table (6) shows the water consumption of winter potato during the seasons from (20112090) divided into averages each ten years of study period and it has been observed that, the lowest water consumption of winter potato has been observed during (2011-2020) period in Dakahlia and Middle Egypt 
governorates, and not determined to specific period in the upper Egypt governorates, while the highest water consumption has been observed during (2081-2090) period in all governorates. Also it has been found that Behera and Aswan governorate were the lowest and highest winter potato water consumption in current and future condition respectively.

Table 6:-Average water consumption amount ( $\mathrm{m}^{3} /$ feddan) for winter potato crop in the periods form (2011-2020) up to $(2081-2090)$.

\begin{tabular}{|c|c|c|c|c|c|c|}
\hline \multicolumn{7}{|c|}{ Winter Potato } \\
\hline Date & Dakahlia & Behera & Beni Suef & Giza & Sohag & Aswan \\
\hline $\mathbf{2 0 1 1}-\mathbf{2 0 2 0}$ & 1281 & 1231 & 1340 & 1401 & 1645 & 1904 \\
\hline $\mathbf{2 0 2 1}-\mathbf{2 0 3 0}$ & 1305 & 1248 & 1367 & 1426 & 1632 & 1952 \\
\hline $\mathbf{2 0 3 1}-\mathbf{2 0 4 0}$ & 1304 & 1247 & 1388 & 1442 & 1683 & 1975 \\
\hline $\mathbf{2 0 4 1}-\mathbf{2 0 5 0}$ & 1337 & 1285 & 1447 & 1497 & 1709 & 1956 \\
\hline $\mathbf{2 0 5 1}-\mathbf{2 0 6 0}$ & 1291 & 1236 & 1403 & 1443 & 1728 & 1549 \\
\hline $\mathbf{2 0 6 1}-\mathbf{2 0 7 0}$ & 1334 & 1273 & 1418 & 1471 & 1717 & 2001 \\
\hline $\mathbf{2 0 7 1}-\mathbf{2 0 8 0}$ & 1854 & 1224 & 1398 & 1442 & 1715 & 2010 \\
\hline $\mathbf{2 0 8 1}-\mathbf{2 0 9 0}$ & 1910 & 1297 & 1473 & 1524 & 1768 & 2028 \\
\hline
\end{tabular}

The rate of change in water consumption of winter potato in relative to (2011-2020) period has been calculated and the result has been shown in figure (6) which indicated that, Dakahlia governorate is most affected by climate change condition in 2070 and 2080 decades where the water consumption during them has been increased by about 45 and $50 \%$ than the base period, also it has been found that the decrement rate that observed in Aswan during 2050 decade has been reached to about $20 \%$ lower than the base period and it's worth to mention that the increment rate of Lower Egypt governorate during this decade also is negligible. The lowest governorate affected by climate change condition in terms of water consumption was Behera while the highest effect, if we ignore the Dakahlia extreme, will be in Aswan governorate.

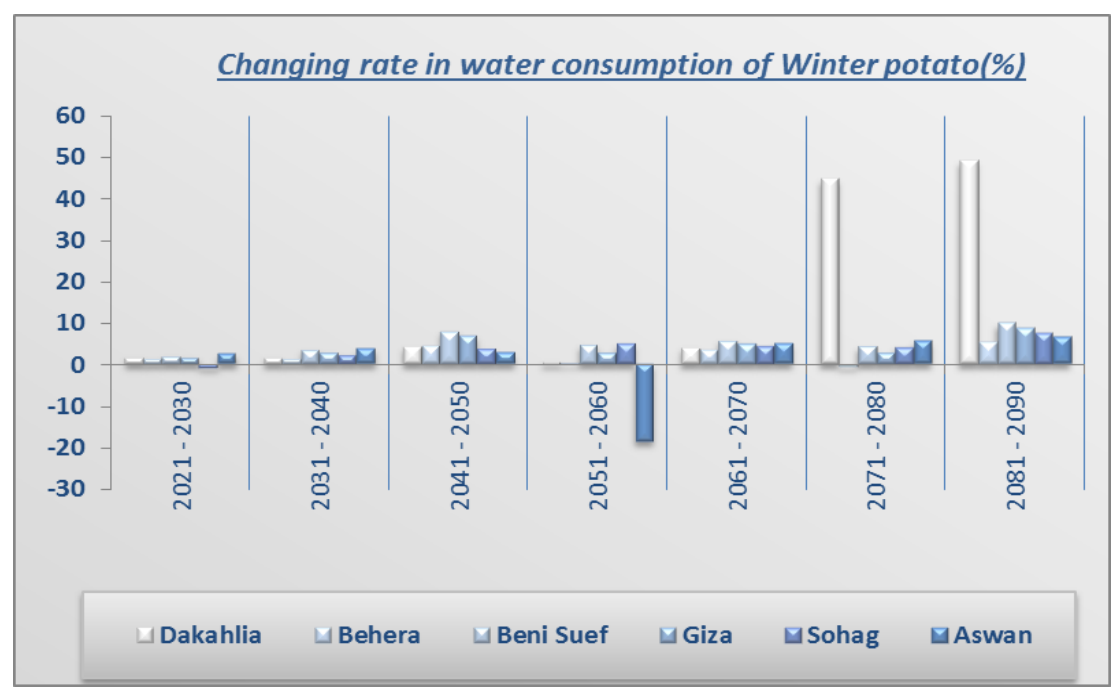

Figure 6:-Changing rate percentage than (2011-2020) in water consumption of winter potato crop at selected governorates.

\section{Winter Tomato:-}

Tomato crop of winter season has been studied in the governorates of Sharqia\& Ismailia in Lower Egypt, Faiyum\& Giza in Middle Egypt, and Qena\&Sohag in Upper Egypt which are the highest agricultural area in each region according to (BAS, 2013) Table (6) shows the water consumption of winter tomato during the seasons from (20112090) divided into averages each ten years of study period and it has been observed that, water consumption of winter tomato is increasing with time and (2011-2020) period has the lowest values, while the highest water 
consumption has been observed in (2081-2090) period in all studied governorates. Also it has been found that Ismailia and Sohag governorate were the lowest and highest winter tomato water consumption in current and future condition respectively.

Table 6:-Average water consumption amount ( $\mathrm{m}^{3} /$ feddan) for winter tomato in the periods form (2011-2020) up to (2081-2090).

\begin{tabular}{|c|c|c|c|c|c|c|}
\hline \multicolumn{7}{|c|}{ Winter Tomato } \\
\hline Date & Sharqia & Ismailia & Faiyum & Giza & Qena & Sohag \\
\hline $\mathbf{2 0 1 1}-\mathbf{2 0 2 0}$ & 1658 & 1550 & 1628 & 1706 & 1960 & 1992 \\
\hline $\mathbf{2 0 2 1}-\mathbf{2 0 3 0}$ & 1689 & 1604 & 1669 & 1745 & 1972 & 2002 \\
\hline $\mathbf{2 0 3 1}-\mathbf{2 0 4 0}$ & 1713 & 1620 & 1699 & 1775 & 2039 & 2069 \\
\hline $\mathbf{2 0 4 1}-\mathbf{2 0 5 0}$ & 1736 & 1626 & 1736 & 1807 & 2021 & 2068 \\
\hline $\mathbf{2 0 5 1}-\mathbf{2 0 6 0}$ & 1704 & 1599 & 1708 & 1782 & 2088 & 2111 \\
\hline $\mathbf{2 0 6 1}-\mathbf{2 0 7 0}$ & 1720 & 1607 & 1724 & 1799 & 2076 & 2102 \\
\hline $\mathbf{2 0 7 1}-\mathbf{2 0 8 0}$ & 1702 & 1591 & 1712 & 1777 & 2086 & 2123 \\
\hline $\mathbf{2 0 8 1}-\mathbf{2 0 9 0}$ & 1782 & 1697 & 1789 & 1860 & 2140 & 2161 \\
\hline
\end{tabular}

The rate of change in water consumption of winter tomato in relative to (2011-2020) period has been calculated and the result has been shown in figure (7) which indicated that, the water consumption of tomato crop will increase than base period in all studied governorates during study period. The rate of increment was lowest in 2020 decade where it has been ranged between 1 - 3\%, while it was the highest in 2080 decade and has been ranged between $7-10 \%$ among the studied governorates.

The lowest governorate affected by climate change condition in water consumption of tomato crop was Sharqia while the highest effect has been observed in Faiyum governorates.

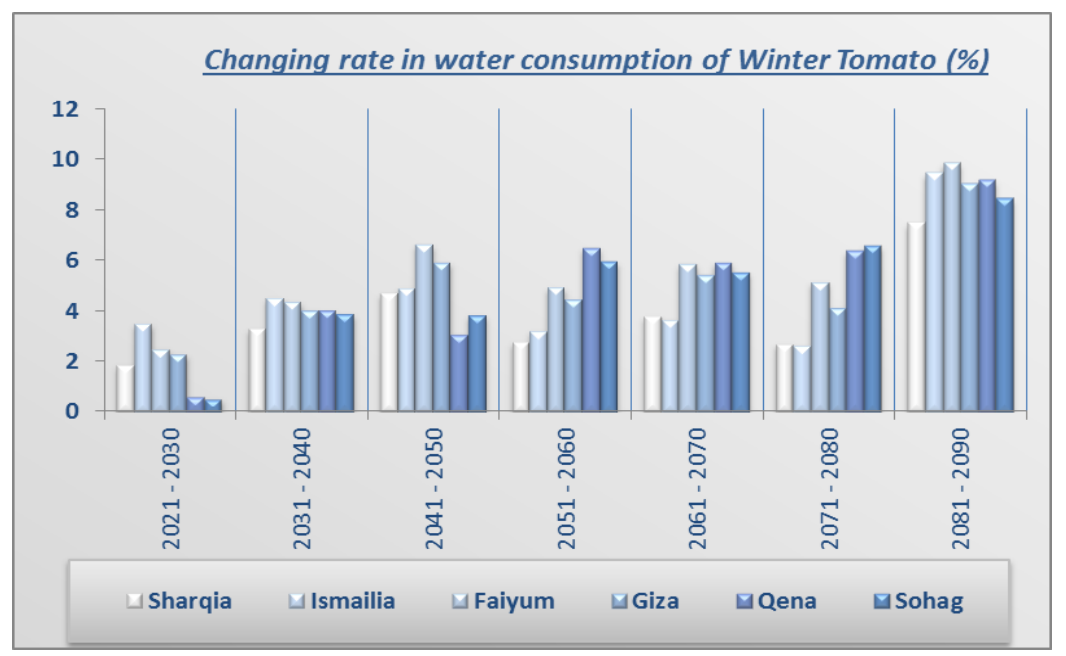

Figure 7:- Changing rate percentage than (2011-2020) in water consumption of winter tomato crop at selected governorates.

In general, these results are in accordance with (Khalil A.A.,2013) which recorded that, the evapotranspiration increased under climate change in Egypt. Water consumption under climate change in Egypt should be developed to mitigate the negative effects of climate change on evapotranspiration. (Gamal El Afandi and Mohamed Abdrabbo, 2015) evaluated the reference evapotranspiration equations under current climate conditions of Egypt and found that Egypt had divided into three agro-climatic regions (Nile Delta in the north, middle and Upper Egypt) according to the mean annual temperature (1971-2000) and the reference evapotranspiration measurements (19982007). Also similar results obtained by (Abdrabbo M. A. A. et al. 2013) who reported that under climate change 
conditions, achieving greater water productivity is the primary challenge for scientists in agriculture. Therefore, changing irrigation schedule could provide a cheap and easy to implement irrigation management techniques to relief the harm effect of climate change, with no additional economic costs.

Similar predictions was reported by (Abdrabbo M. A. A., et al. 2016) who mentioned that the irrigation requirements increased depending on climatic region and climate change scenarios and the expected climate changes in Egypt according to the RCPs scenarios will cause an increase in annual ETo depending on the climate region. In the same line (Farag A.A. et al. 2015) study the impact of climate change on irrigation water Demand for rice crop in Kafr el-sheikh Governorate, and they found that the total amount of irrigation water demands increased per feddan per year ranging from 348 to $1370 \mathrm{~m}^{3}$ in Kafr El-Sheikh Governorate under different climate change RCP scenarios and water budget under climate change scenarios in the same Governorate will increase, ranging from 92 to 354 million cubic meters.

More adaptation options need to be studied under Egyptian condition. Climate change not only affects the spatial and temporal distribution of water resources, but also will increase the crop evapotranspiration, heightening the instability and imbalance of the supply and demand of agriculture water resources (Oki and Kanae 2006; Piaoet al. 2010).These options, if implemented, will save on the applied irrigation water, which can be used to irrigate new lands under climate change conditions, which will contribute in maintaining the current production (Oudaet al. 2016).

\section{Conclusion:-}

Finally, it is undoubtedly that irrigation water use pressure will further aggravate under future climate change and since surface irrigation is prevailing in Egypt with low application efficiency, it is important to test options to increase it. The results indicated that, climate change conditions expected to increase ET values for all governorates in Egypt, consequently, a water requirement which is most affected in Upper Egypt area and specific regions in Lower Egypt area. Also the extreme decrement will effect during 2050 and 2060 decades in Aswan and Minya governorates which may be good sign in terms of water requirement but should be study it in other terms where it may be negative condition for it, such as, pests and plant disease, Moreover, extreme increment will effect during 2070 and 2080 decades in Dakahlia governorate and so on all crops in it. Also the study conclude that, the impact of climate change is systematic and acceptable up to 2040 for the studied crops among the determined governorates and it does not excessed 5\% than its current condition, however, after this period the rate of increment transit to higher stage, sharp extreme effects appeared in some regions

\section{Acknowledgement:-}

We would like to express our gratitude towards the project of "Regional climate change database for agriculture sector in Egypt" which funded by Science \& Technology Development Fund (STDF) for supporting this research.

\section{References:-}

1. Abdrabbo, M. A. A., Ouda,S., and Noreldin, T. (2013):Modeling the Irrigation Schedule on Wheat under Climate Change Conditions. Nature and Science, 2013; 11 (5): 10-18.

2. Abdrabbo, M. A. A., Saleh, S. M., andFarag, A. A. (2016): Water requirements for maize under climate change. Journal of Applied Sciences Research, 12(5): 19-28.

3. Allen, R. G., Pereira, L. S., Raes, D. and Smith, M. (1998): Crop evapotranspiration. Guidelines for computing crop water requirement. FAO Irrigation and Drainage Paper 56, Food and Agriculture Organization, Rome, Italy.

4. Eid, H. M., and N. M. El-Mowelhi. 1998. Impact of climate change on field crops and water needs in Egypt. African International Environmental Conf. Oct, 1998, Egypt.

5. El-Shirbeny, M. A., Abd-Elraouf, M. A., and Nasser H. S. (2014): Crop Water Requirements in Egypt Using Remote Sensing Techniques" Journal of Agricultural Chemistry and Environment, 3, 57-65.

6. El Afandi, G. and Abdrabbo, M. A. A. (2015): Evaluation of Reference Evapotranspiration Equations under Current Climate Conditions of Egypt. Turkish Journal of Agriculture - Food Science and Technology, 3(10): 819-825, 2015.

7. Khalil, A.A. (2013): Effect of climate change on evapotranspiration in Egypt. Researcher 2013;5(1): 7-12.

8. Ministry of Water Resources and Irrigation (MWRI) in Egypt.Water Scarcity in Egypt report, February 2014.

9. Niang, I., Ruppel, O. C., Abdrabo, M. A., Essel, A., Lennard, C., Padgham, J., and Urquhart, P.: Africa, in: Climate Change 2014: Impacts, Adaptation, and Vulnerability, Part B: Regional Aspects, Contribution of 
Working Group II to the Fifth Assessment Report of the Intergovernmental Panel on Climate Change, edited by: Barros, V. R., Field, C. B., Dokken, D. J., Mastrandrea, M. D., Mach, K. J., Bilir, T. E., Chatterjee, M., Ebi, K. L., Estrada, Y. O., Genova, R. C., Girma, B., Kissel, E. S., Levy, A. N., MacCracken, S., Mastrandrea, P. R., and White, L. L., Cambridge University Press, Cambridge, UK and New York, NY, USA, 1199-1265, 2014.

10. Oki, T, and Kanae, S. (2006): Global hydrological cycles and world water resources. Science 313(5790):10681072.

11. Ouda, S., Khalil, F., El Afendi, G., and Abd El-Hafez, S. (2011): Prediction of total water requirements for agriculture in the Arab World under climate change.15th International Water Technology Conference. 11501163.

12. Ouda, S., Noreldin, T., and Abd El-Latif K. (2015): Water requirements for wheat (Triticum spp.) and maize (Zea mays) under climate change in north Nile Delta. Span. J. Agric. Res. 13(1):1-10.

13. Piao, S. L., Ciais, P., Huang, Y., Shen, Z. H., Peng, S. S., Li, J. S., Zhou, L. P., Liu, H. Y., Ma, Y. C., Ding, Y. H., Friedlingstein, P., Liu, C. Z., Tan, K., Yu, Y. Q., Zhang, T. Y., and Fang, J. Y. (2010): The impacts of climate change on water resources and agriculture in China. Nature 467(7311):43-51.

14. Ouda S., Khalil, F.,ElAfendi,G., and Abd El-Hafez, S. (2011): Prediction of Total Water Requirements for Agriculture in The Arab World Under Climate Change. Fifteenth International Water Technology Conference, IWTC-15 2011, Alexandria, Egypt.

15. Ouda S., El-Latif, K.A., and Khalil, F.(2016): Chapter two of 'Water Requirements for Major Crops': Major Crops and Water Scarcity in Egypt. Springer Briefs in Water Science and Technology, DOI 10.1007/978-3-31921771-0_2.

16. United Nations Development Programme (UNDP), (2013): Potential Impacts of Climate Change on the Egyptian Economy report Cairo, Egypt.

17. http://www.eeaa.gov.eg/portals/0/eeaaReports/CCRMP/6.\%20Potential\%20Impact\%20of\%20Climate\%20Chan ge\%20on\%20the\%20Egyptian\%20Economy/Potential\%20Impact\%20of\%20CC\%20on\%20the\%20Egyptian\%2 0Economy\%20English.pdf 